\title{
How Does LG Group Embed Enterprise Risk Management (ERM) System In Its Conglomerate Governance To Control Its Affiliated Firms' Risk Events?
}

\author{
Sangil Kim, Ajou University, South Korea
}

Jungmin Yoo, Hongik University, South Korea

\begin{abstract}
This paper presents a case of enterprise risk management (ERM) embeddedness in LG Group, globalized conglomerate in Korea. Findings are differentiated from prior studies in two aspects. First, this study focuses on how ERM systems minimize the agency costs between conglomerate headquarters and its affiliated firms. Second, cases of diversified twelve affiliated firms find that COSO ERM framework are to be applied adaptively to entities' inherent or external conditions as industry, age, management level etc. Those findings might be a practical guidance for most Asian business groups to embed ERM frameworks in conglomerate governances, filling gaps between theoretical COSO manual and practical applications.
\end{abstract}

Keywords: Enterprise Risk Management; Conglomerate Group; Affiliated Firms; Agency Cost

\section{INTRODUCTION}

¿ n 2002, Korean financial market had suffered another nation-wide shock since Asian Economic Crisis in 1997. It was called as "Korean Credit Card Distress" which was caused by credit delinquents' bad debts of seven domestic credit card corporations. As Standard and Poor's denoted that it might cost $\$ 8.4$ billion, $1.3 \%$ of national GDP to stabilize seven credit card corporations ${ }^{1}$, it left huge aftereffects. LG Card corporations, a LG affiliated firm was also in the center of the distress. And it was resulted from managers' moral hazards which were not detected by internal control systems. Then CEO issued credit card imprudently even to the lowest credit ratings to increase its market share which is his key performance indicator in a competitive market. Though managers of LG card had noticed inherent default risks, they reluctantly refuse to report them to group headquarters not to be bothered in pursuit of their short-sighted performance goals. LG Card Corporation, one of the biggest credit card companies in South Korea, went bankrupt. Once the most profitable entity among conglomerate which had recorded net income of $\$ 330$ million with the biggest domestic market share in 2000 was sold at dirt cheap price.

LG Card case showed that agency costs derived from information asymmetry in conglomerate group might lead to fatal losses unless it is detected beforehand by the group headquarters. It is well known that managers intentionally conceal inherent information which might shed negative effects on their performance goals, which resulted in severe agency costs (Demsetz \& Lehn, 1985; Jensen \& Meckling, 1976). Agency costs can be lowered through appropriate monitoring on managers which eventually minimize information asymmetry between managers and shareholders (Ball, Kothari, \& Robin, 2000). Prior studies in financial accounting or internal control management proved that the announcement of reliable accounting information or effective monitoring on managers' performances minimize agency costs (Verrecchia, 1983; Bushman \& Smith, 2001). However, aftermath methods focusing on accounting results or managers' performances cannot substitute information asymmetry incurred form risk factors beforehand (COSO, 2004). ERM framework is expected to lower agency cost significantly through sharing information of risks

${ }^{1}$ MONEYTODAY, "S\&P, credit card distress may degrade credit ratings of Korean banks" 2004-01-14 
factors beforehand. LG Card distress also might escape the serious agency costs, if the information of credit delinquents' bad debts which preceded being bankrupt were monitored earlier.

ERM, one of such internal control system, is defined as "a process, effected by an entity's board of directors, management and other personnel, applied in strategy setting and across the enterprise, designed to identify potential events that may affect the entity, and manage risks to be within its risk appetite, to provide reasonable assurance regarding the achievement of the entity's objectives" (COSO, 2004, page 13). Proposed by the Committee of Sponsoring Organizations of the Treadway Commission (COSO) in 2004, ERM systems enable managers to detect and internally control plausible risk events which might interfere with attaining business goals beforehand (McNamee and Selim, 1998). In this sense, ERM systems play an effective role in managing uncertainty in the courses of attaining strategic, operational, and financial objectives of entities. Thus, ERM integrates enterprise-wide risks and supports organizations to set an optimal strategy (Meulbroek, 2002).

So far, very little has been done on the role of ERM mitigating agency costs for conglomerate group. Prior studies on ERM are targeted for individual firms. And the topics have been categorized into two; one is to identify characteristics of early adopting firms (Liebenberg \& Hoyt, 2003; Pagach \& Warr, 2011) and the others examine the effects of ERM adoptions (Hoyt \& Liebenberg, 2011; Gordon, Loeb, \& Tseng, 2009). There also have been a few case studies of ERM for individual firms. Those prior studies. Most studies have been centered on the roles of ERM which prevent plausible risk events through its early warnings processes. To date, there has been minimal research regarding the role of ERM in mitigating agency cost in entities.

Presented with ERM embeddedness in conglomerate group, this study extends prior studies with two differential contributions. First, this study explores how ERM reduces agency costs arisen between the corporate headquarters and the managers of affiliated firms in a conglomerate. Implementing ERM to mitigate agency costs among headquarters and affiliated firms requires additional considerations which are not in independent firms. This paper proposes those examples with actual proofs. Examples are in an additional factor for headquarters to minimize agency costs in evaluating risk events, the efforts to contrive for key risk indicators be reported to headquarters in due time to prevent managers' moral hazard, building a sustainable ERM systems among headquarters and affiliated firms. Second, this paper suggests that ERM embeddedness varies depending on the industries, ages, or other entities specifications with the case of 12 affiliated firms. COSO framework provides basic principles for implementing the systems rather than giving detailed guidelines or suitable techniques to apply to each organization (O'Donnell, 2005). A survey for ERM officers in adopting firms also reveals that $26.5 \%$ of respondents responded that the COSO ERM Framework is generally ambiguous guided, and $44.6 \%$ responded that the framework is overly theoretical (Beasley, Branson, \& Hancock, 2010). For example, the patterns of risk profiles or evaluation methods were different depending on their ages, industries. On the other hand, for a certain firm as LG International, serious losses were caused by repetitions of precedent risk events due to the failure to share findings of the past accidents. In such cases, building a well-designed risk management systems to share pre-existing preventive outcomes was much more important rather than defining dozens of newly defined risk profiles or risk indicators. With plentiful evidences convincing those two contributions, we expect for this study to be a practical and specified guidance for other diversified conglomerates that are common particularly in East Asia and West Europe.

\section{CASE DESCRIPTION}

\section{Motivation of ERM Embeddedness}

Business group LG is one of major conglomerates, namely 'chaebols' in Korea. Starting its business in trading and chemical industries in 1947, it has achieved a remarkable growth with $\$ 134.9$ billion of sales through over than 200,000 employees as now. In 2012, LG Corp., its holding company holds 49 affiliated firms, in diversified industries as electronics, LCD panel, chemicals, communications, financial services etc. With its rapid growth, its management skills have been advanced up to global standards. Here, conglomerate headquarters plays its controlling roles for affiliated firms in setting business strategies, evaluating executives' performances, and maintaining core values of entire organization etc. However there still exists the dead-zone of management. 
There were two main motivations for LG group to proactively implement ERM systems. First, LG group had transformed its corporate governance into holding company systems in 2002, which emphasizes the independences of management of each affiliated firm. It meant that the central controlling power of conglomerate headquarters had been weakened. Second, Korean credit card distress in 2002 initiated by bankruptcies in credit card business evoked Korean chaebols to scrutinize agency costs among conglomerate headquarters and those affiliated firms. Series of financial distress and transformations asked LG group to contrive a sophisticated and efficient device to internally monitor its affiliated firms. Then COSO 2004 ERM framework emerged as a supplementary management tool to meet the needs of LG conglomerate and affiliated firms. The case of ERM embeddedness in LG provides desirable setting which lacks in prior case studies in several aspects. Equipped with 12 diversified industries of affiliated firms, this study may provide practical benchmarks for the firms to overcome the ambiguity of COSO guidelines. We also expect that this case may provide East Asian or West European business conglomerates with experiential advices on how to maintain centralized internal control systems in accordance with independent management of each affiliated firm.

\section{Research Methodology}

This study is structured in a typical case research. Sample firms are twelve affiliated firms of LG business group which implemented ERM framework during the year of 2004 to 2006. And we also include the aftermath settlement stage driven by IAS and LGERI staff which were the driving forces of corporate headquarters. The intermediate and final outcomes of this study are based on the actual projects of twelve affiliated firms. We followed every steps on which ERM TFT carried out. And the outcomes were the results of field interview, TFT executions, process analysis etc. For example, interviews covered those participants of ERM adoption in each affiliated firm, members of ERM TFT, executives and managers of each risk owners. The size of interviewees are more than 100 personnel for each affiliated firm covering risk officers, executives, employees at work site. Interviews have been initiated by in-house consultants of LGERI, one of co-authors joined the TFT from its pilot embeddedness in LGA to constructing ERM management systems at conglomerate level. And other meaningful offerings are found in actual outcomes of ERM implementation such as risk profiles, evaluation, solution for each key risk, risk reporting process etc. Although based on COSO 2004 ERM manual commonly, those final realizations were differentiated adapting the ERM needs of each firm. These were the courses to give shapes of ambiguity of ERM manual into each affiliated firm.

\section{LG's Approach on ERM Embeddedness}

The ERM embeddedness in LG Group was motivated for top managers of conglomerate headquarters in order to monitor business risks of its affiliated firms. Thus the internal auditing staffs of the conglomerate headquarters (IAS) took the part of in charge of whole implementing process. The main role of IAS was to execute internal auditing on affiliated firms, and to inspect fraud affairs when requested. As IAS resumed the control of ERM implementation, its roles turned into being more proactive than before to prevent plausible strategic risks in advance. Thus, based on the COSO 2004 framework, its roles also were expanded to monitor not only operating risks or frauds but also strategic risks of affiliated firms. Due to the role shift, IAS depends on its professional jurisdiction in carrying out the whole processes of risk managements of conglomerate and its affiliated firms (Page \& Spira, 2004; Fraser \& Henry, 2007).

LG followed stepwise manners in its implementations, to apply first to a test bed firm then to spread the know how to other affiliated firms. Thus LGA ${ }^{2}$ was selected as a test bed firm on account that the chemical industry of LGA shows a relatively simple operating process. In early 2004, a task force team of ERM (ERM TFT) initiated by Price Waterhouse Coopers $(\mathrm{PwC})$ had been organized. However, even though PwC staffs had executed some ERM projects before for domestic financial firms, there were uncertainties whether they could manage ERM implantation into manufacturing industries as LG. In consideration of the uncertainties, ERM TFT was organized with diverse sources including consulting staffs of PwC, field workers of LGA, in-house consulting staffs of LG Economics Research Institute (LGERI) and leading staffs of IAS. Here in-house consulting staffs of LGERI took its important role to spread out the learnings from LGA into other affiliated firms. In the stage of spread out, LGERI planned to take a leading role of each embeddedness without PwC staffs. By this, LG group was favored by side effects to minimize leakages of confidential business information.

\footnotetext{
${ }^{2}$ The name of each affiliated firm has been anonymously, requested by firms.
} 


\section{FOUR STAGES OF ENTERPRISE RISK MANAGEMENT(ERM) SYSTEMS EMBEDEDNES}

COSO 2004 ERM framework introduces eight interrelated components of ERM - internal environment, objective setting, event identification, risk assessment, risk response, control activities, information and communication, and monitoring. We reorganized those components into five implementing stages to provide better understanding. Stage one is to set objectives of ERM systems each firm. Stage two is to select key risks through risk event identification and evaluation. Stage three is to propose solutions for risk events such as risks indicators (RI) and corrective actions (CA). Stage four is to build Risk Management Systems (RM) for ERM to be sustainable. And the last stage is on how to motivate affiliate firms over some obstacles which still remains even after the implementations had been completed. In each stage, we provide substantial evidences of affiliated firms which were not proposed in prior studies (Liu, Zou, \& Gong, 2013). Those differential aspects are caused by two differential aspects in that this case is on conglomerate group which holds diversified affiliated firms.

\section{Stage One: Setting ERM Objectives for Conglomerate and its Affiliates}

Setting objectives of ERM for a conglomerate group are differentiated in two aspects from ones for individual firms. First, TFT needs to clarify that each affiliated firm holds its own needs or focuses on ERM systems. Second, due to the conflicts of expectations on ERM implementations among headquarters and its affiliated firms, the inconsistent objectives are to be coordinated.

For the first difference, the objectives of ERM implementations were widely different among affiliated firms of LG reflecting their business characteristics. One of the reasons was that COSO 2004 guidelines compass not only operational but also strategic risk events. While the adaptive applications to individual entity is one of the distinguishable aspect of COSO 2004 ERM framework, it lacks to provide actual applicable guidance on how to implement into differential cases. Though strategic risks differ as to industries because strategy of a firm is a mixture of the threat of substitute products or services, the threat of established rivals, and the threat of new entrants, the bargaining power of suppliers and the bargaining power of customers (Porter, 2008). Generally, internal control systems as ERM are to be linked to strategy of each firm (Brickley, Smith, \& Zimmerman, 1997; Ittner, Larker, \& Randall, 2003). For example, LGB in international trading business asked ERM to focus on trading regulations and processes which resulted in huge bad debts losses when they were not complied with. On the other hand, LGC in domestic ATMs (Automatic Teller's Machines) oligopoly industry needed to focus strategic risks especially to monitor its rivals in competitive market.

Concerning the second differential aspect of setting ERM objectives, initiatives of ERM implementations came from LG conglomerate headquarters by top-down manners. LG group tried to prevent recurrences of risk events which caused by agency costs and information asymmetries between managers of affiliated firms and conglomerate headquarters. Sometimes it resulted in tremendous losses in conglomerate performance as in LG card distress. Thus, the ultimate objective of headquarters was to design advanced early warning systems that inherent plausible risk events of affiliated firms were reported in timely manners. Eventually IAS aimed to reduce agency costs at conglomerate level and tried to minimize the dead zone of internal control systems. However, each affiliated firm also expressed its customized needs for ERM systems which are incompatible with ones of LG headquarters. ERM TFT could not ignore those needs of affiliated firms who paid for consulting fees. Also, affiliated firms were the project owners who take the control of ERM systems from embeddedness to routine operations. Dilemma was how to coordinate the conflicts of ERM needs among the conglomerate headquarters and its affiliated firms. ERM TFT assumed that if the implemented ERM was not useful for each firm, it would not be accepted as sustainable management tool. Finally, TFT coordinated conflict interests as follow. While affiliated firms might identify risk profiles of their own needs, headquarters' needs also could be imbedded in evaluating risk event and selecting key risks which were to be monitored by headquarters. Also, there were some considerations to mitigate agency cost of conglomerate level such as adjusting monitoring intervals of KRI adaptive to headquarters needs, and executing IAS' external auditing whether information provided by affiliated firms were reliable or not.

\section{Stage Two: Identifying and Evaluating Risk Events}

In stage two, TFT identified risk events which resulted in risk profiles and evaluated risk events to select key risks which were to be cared in priority. For these activities, LG case was differentiated in three aspects; applying LG 
adaptive profiling methods, considering headquarters needs into evaluation factors in order to minimize agency costs among conglomerate, and diversified outcomes of affiliated firms in their risk profiles and evaluations.

First, TFT applied LG adaptive, rather efficient and effective methods in risk identifications. COSO guidelines provide examples of event identification activities, they do not provide a detailed description of procedures that an organization could use to analyze business processes and to identify events that should be considered during risk assessment. ERM TFT of LG faced a severe trial and errors to apply those theoretical methods. At first, PwC proposed and applied business processes analysis to identify risk events of LGA. Based on bottom-up approach, this method analyzes the business processes, functions, and divisions to find all the plausible risk events in detail (Knechel, 2002). Thus, this method requires as much efforts and time as to cover whole the processes. However, this method was no longer effective and efficient for manufacturing industries. For example, to define risk events only in quality control (QC) process in chemical interior materials department, eight members of PwC, the LGERI, LGA spent over 10 hours. And they draw on more than 100 risks events from a quality control process only. Then, ERM TFT changed its risk identification methods to be more efficient and effective in three aspects. Above all, they referred to risk events of the past. Second, they proceeded top-down approach to identify significant risks by interviewing executives of each function or business division. Third, TFT also spend some hours on identifying strategic risks through external industry experts as financial analysts, suppliers, major customers etc. Bottom-up approach also has its strengths though which is more suitable for the financial industries in which a little error may cause serious losses and its business processes are rather simple and routine. A new identification method saved much time and effort with even more satisfactory results, risk profiles. Since then TFT applied the same risk identification processes to all the other LG affiliated firms. Figure 1 shows the overview if identification methods which were adaptive to LG affiliated firms, and Table 1 shows the risk profiles induced through this process. It presents some risk profiles for the sales team of LGC which produces electronic goods as LEDs and parts of mobile phones.

Figure 1. Risk identification process summary corresponding to ERM needs

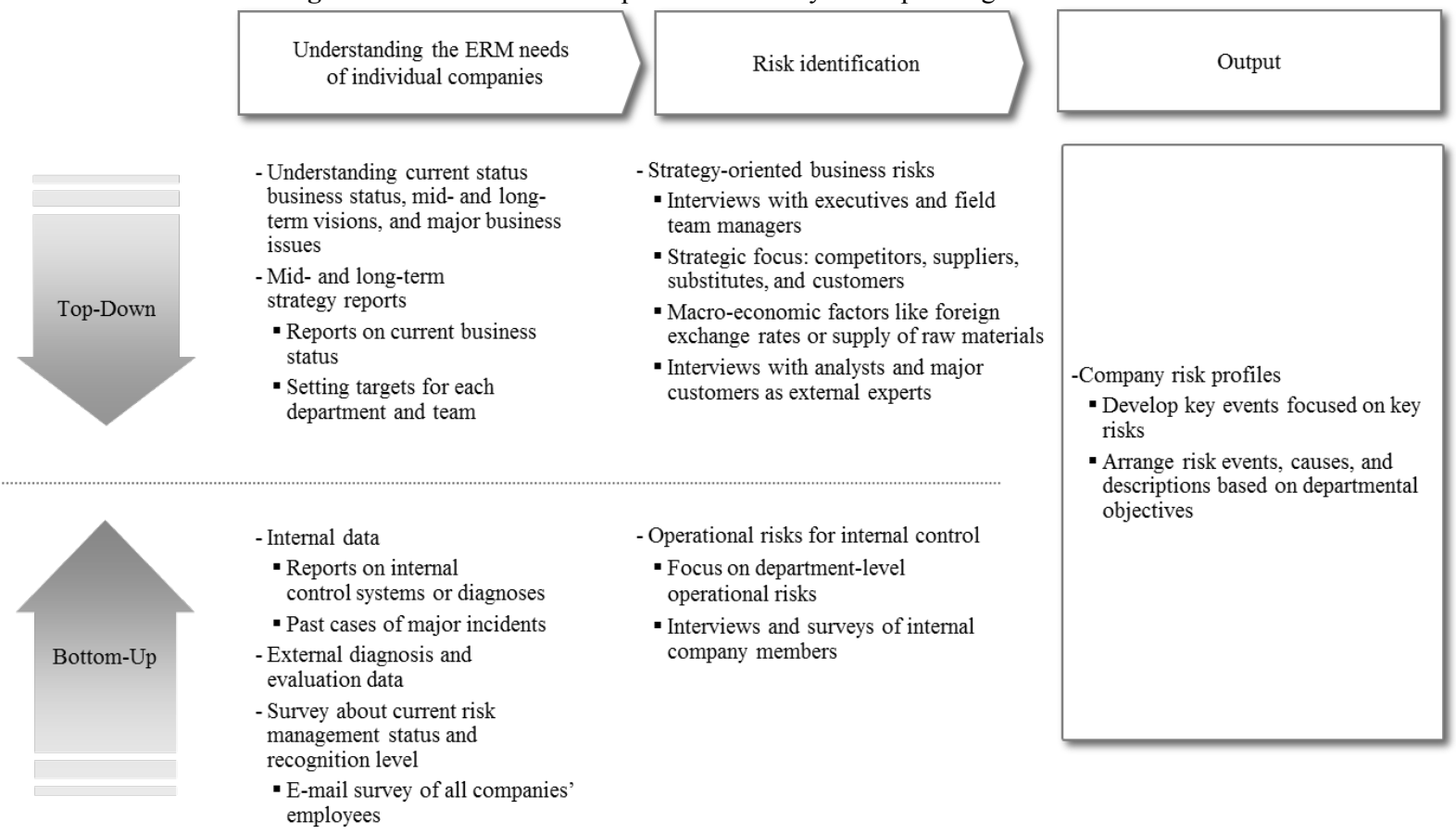

Source: ERM implementation project final report at LG 
Table 1. Example of risk profile (LGC)

\begin{tabular}{|c|c|c|c|c|}
\hline \multirow{10}{*}{$\begin{array}{l}\text { Objective } \\
\text { Develop } \\
\text { new } \\
\text { market }\end{array}$} & \multirow{10}{*}{$\begin{array}{l}\text { Risk Event } \\
\text { Lack of } \\
\text { operational } \\
\text { competitive- } \\
\text { ness }\end{array}$} & \multicolumn{2}{|c|}{ Cause } & \multirow{10}{*}{$\begin{array}{l}\text { Description (Loss) } \\
\text { - Limitation to obtain existing } \\
\text { information through external } \\
\text { sources } \\
\text { - Currently held operating } \\
\text { information is limited to } \\
\text { information about the address, } \\
\text { level, area, and owner. It is } \\
\text { necessary to add more } \\
\text { information, like contract period, } \\
\text { person in charge, and description } \\
\text { of the building, etc.; Regular } \\
\text { renewal and sharing of the } \\
\text { information with related persons } \\
\text { in charge are necessary. } \\
\text { - Lack of a network to obtain } \\
\text { advanced construction information } \\
\text { in remodeling businesses like } \\
\text { funds or REITs firms. } \\
\text { - Case (1) Failure to win a bid } \\
\text { owing to high bidding price. } \\
\text { - Case (2) Failure to get an order } \\
\text { owing to lack of negotiation } \\
\text { power with the client firm at the } \\
\text { final stage of the private contract. }\end{array}$} \\
\hline & & $\begin{array}{l}\text { Lack of fundamental } \\
\text { operational competitiveness }\end{array}$ & $\begin{array}{l}\text { Absence of operational } \\
\text { information collection } \\
\text { network }\end{array}$ & \\
\hline & & & $\begin{array}{l}\text { Weak database and } \\
\text { information management } \\
\text { systems }\end{array}$ & \\
\hline & & \multirow[t]{3}{*}{$\begin{array}{l}\text { Lack of competitiveness to } \\
\text { make private contracts }\end{array}$} & $\begin{array}{l}\text { Failure to maintain close } \\
\text { relationship with the key } \\
\text { men at each client firm }\end{array}$ & \\
\hline & & & $\begin{array}{l}\text { Lack of human resources } \\
\text { in each specialized area }\end{array}$ & \\
\hline & & & $\begin{array}{l}\text { Failure to secure cost } \\
\text { information for own firm } \\
\text { and competitors }\end{array}$ & \\
\hline & & \multirow[t]{2}{*}{$\begin{array}{l}\text { Lack of competitiveness to } \\
\text { attract bid contracts }\end{array}$} & $\begin{array}{l}\text { Weak price } \\
\text { competitiveness of } \\
\text { cooperative firms }\end{array}$ & \\
\hline & & & $\begin{array}{l}\text { Lack of presentation and } \\
\text { negotiation capacities }\end{array}$ & \\
\hline & & \multirow{2}{*}{$\begin{array}{l}\text { Lack of support to develop } \\
\text { operational human } \\
\text { resources }\end{array}$} & $\begin{array}{l}\text { Shortage of exclusive } \\
\text { human resources for sales }\end{array}$ & \\
\hline & & & $\begin{array}{l}\text { Inappropriate job } \\
\text { placement }\end{array}$ & \\
\hline
\end{tabular}

Second, LG added the third evaluation factor in order to select key risks in terms of minimizing agency costs among headquarters and affiliated firms. TFT evaluated the collections of risk profiles to select key risks to treat in priority. There are types of risk evaluation methods in qualitative or quantitative manners. Qualitative techniques include qualitative scales and factor ratings, risk priority numbers (Franceschini \& Galetto, 2001), or fuzzy approaches (Carr $\&$ Tah, 2001). Quantitative techniques are precise and used for rather complex processes. Theoretically and practically, the widespread techniques are a product of impact and likelihood of risk events (Arena, Arnaboldi, \& Azzone, 2011). In case of LG group, they need to consider the third evaluation factor to minimize agency costs among conglomerate headquarters and affiliated firms. Basically, ownership on ERM systems were on each affiliated firm and its chief risk officer (CFO). Each affiliate was expected to operate autonomously to satisfy at its managerial needs. LG conglomerate headquarters also tried not to intervene in general operations of affiliated firms. Since the motivation of ERM embeddedness was to minimize the agency costs among conglomerate headquarters and affiliated firms, ERM system of each affiliated firm were required to compromise its autonomy and intervention of headquarters. Answer was management sharing on key risk events of each affiliate to be corporate-internally controlled. Applying the third aspect of risk evaluation, ERM TFT selected top ten risk events of each affiliate for which are to be monitored by headquarters. By this, the risks of each affiliated firm of LG Group could be properly balanced between the autonomous area of each firm and the central management control area.

The last differential aspects were on the adaptive outcomes depending on their industries, age, or management levels etc. For example, such firms of LG chemicals, LG electronics which had long histories thus equipped with globalized well defined management routines focused on strategic or business risks rather than operational risks. To the contrary, emerging firms as LG Serveone, LG Nsys which had less than five business years yields more operational risks than strategic risks in their risk profiles.

Outcomes of evaluations were different responding to firm specifications. Generally, evaluation results were used to prioritize risk events to be ungently. However, certain firms whose performances were sensitive to those changes of external factors required more detailed information from evaluations. LG Micron whose total sales were so dependent on the changes of cost of raw material, exchange rate of foreign currencies, or prices of substitute products can be the example. for LG Micron, TFTs tried to capture the impact in financial numbers by managers' the requests. Table 2 shows the numerable evaluations of the risk impact of prices changes of raw materials as LCD, PDP, SM parts 
considering the price of imported raw materials, the foreign currency exchange rate, global supply and demand, and so on.

An interview with the executives revealed that price of raw materials such as LCD, PDP, SM parts significantly influenced financial performance. Providing plausible impacts with concrete numbers was worth enough for top managers of LGH to understand the impact of risks and to figure out the depending plan. There was no such information before as quantitative based impacts of risks before ERM embeddedness. LGH case assures that ERM systems provide information on plausible risk for managers to control in advance to attain their business objectives (McNamee \& Selim, 1998), integrating enterprise-wide risks and supports to contrive realistic response strategy rather than obscure ones (Meulbroek, 2002).

Table 2. Estimation process for strategic risks (LGH)

\begin{tabular}{ll}
\hline Assumptions \\
- & Selling prices decrease risk due to severe competition \\
- & Simulation of the impact of the price by products of each company \\
- & Sales based on the business plan as the beginning of 2005 \\
- & As a result analyzed only for major models amoung the entire products, errors can exist.
\end{tabular}

\begin{tabular}{c|c|c|c} 
Recent panel price trend & & (Unit: US \$) \\
\hline Module price & LCD (42”) & PDP (42”) & SM (29”) \\
\hline '04 4Q & 1,459 & 1,031 & 100 \\
\hline '05 4Q & 963 & 811 & 72 \\
\hline '06 Av. & 789 & 674 & - \\
\hline '07 Av. & 420 & 604 & - \\
\hline
\end{tabular}

Estimated loss on operating income

\begin{tabular}{|c|c|c|c|c|c|}
\hline \multicolumn{5}{|l|}{ Estimated los } & \multirow[b]{2}{*}{$\begin{array}{l}\text { Additional decrease of } \\
\text { operating profits* (4) }\end{array}$} \\
\hline $\begin{array}{c}\text { Business } \\
\text { department }\end{array}$ & Yr & Sales target (1) & $\begin{array}{l}\text { Price decrease rate } \\
\text { on business plan (2) }\end{array}$ & $\begin{array}{l}\text { Additional price decrease } \\
\text { rate by risks (3) }\end{array}$ & \\
\hline \multirow[t]{2}{*}{ PM (Global) } & '05 & 160 billion & $10 \%$ & $3 \%$ & 2.5 billion \\
\hline & '06 & 230 billion & $5 \%$ & $7 \%$ & 8.2 billion \\
\hline \multirow{2}{*}{ PRP } & '05 & 230.1 billion & $7 \%$ & $2 \%$ & 2 billion \\
\hline & '06 & 317.8 billion & $6 \%$ & $2 \%$ & 2.7 billion \\
\hline \multirow{2}{*}{ SM (Global) } & '05 & 319.2 billion & $6 \%$ & $4 \%$ & 3.6 billion \\
\hline & '06 & 27.8 billion & $5.5 \%$ & $4.5 \%$ & 3.3 billion \\
\hline
\end{tabular}

\section{Strategic implications by products}

- LCD: Rapid decrease of price of LCD-TV is traded off with its sales amount when it competes with PDP-TV

- PDP: Due to launce of competetors like Hoya and DNP, the market share is reduced and prie decreased is expected

- SM: The impact of LGOO' DSM drop and sales decrease are expected to be gradually reduced.

\section{Stage Three: To Propose Solutions for Risk Events}

Treatments for each risk events are summarized as internal monitoring by key risk indicators (KRI) and corrective actions (CA). The patterns of treatments were also different concerning industries, management levels etc. Emerging firms as LG Serveone, LG Nsys whose general managements were not settled yet produced more issues in corrective actions than the established firms. On the other hands, there were few corrective actions for globalized firms with long business histories as LG electronics, LG chemicals. For the firms in the competitive market conditions, it was essential to monitor KRIs' to capture changes of external, strategic factors. Treatments start with the process of determining the causes of a certain risk and identifying the main causes. TFTs creatively developed a form of diagram, "Causal Map" for this process to communicate effectively. A causal map shows some connections of causes and effects of a risk event in a simplified diagram. Figure 2 shows a causal map for risk event 'failure of supply chains management' in an affiliated firm, LGF. Among several causes, the causal map indicates two main causes. One is delayed deliveries by suppliers, and the other is inflations of raw materials. Starting from these two main causes, causal map go further even to the root causes. Here, KRI and CA are the most influential and preferential treatment to be managed among 
all the related causes. In the figure, KRI indicates those issues in which early warnings are required through risk indicators. Table 3 shows the collections of CA and KRI for key risks event of LGF.

Figure 2. Causal map of a supply chain management risk event

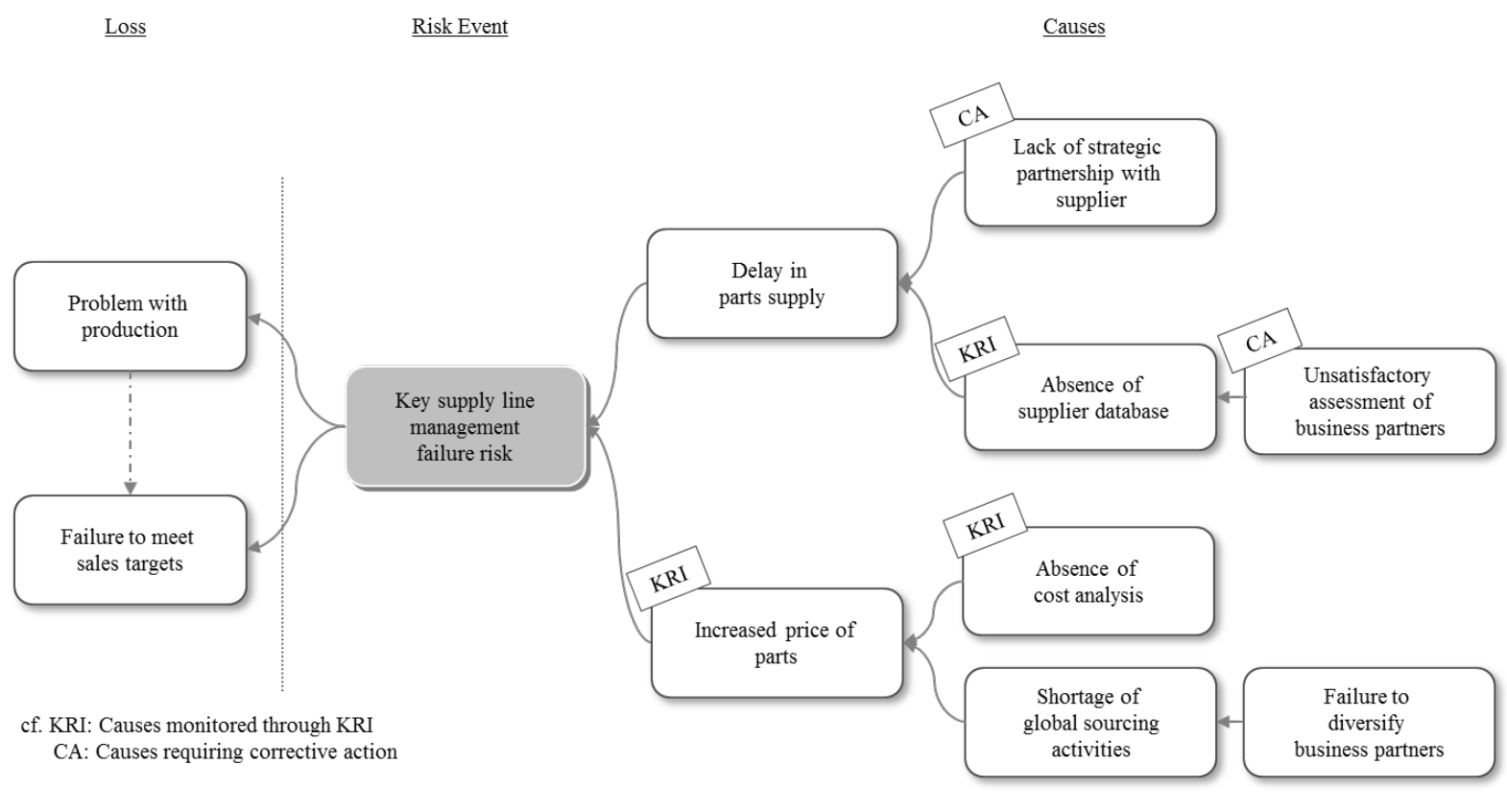

Source: LG-F ERM project materials 
Table 3. Corrective Actions and KRI for key risk events (LGF)

\begin{tabular}{|c|c|c|c|}
\hline Risk Event & Key Issues & Corrective Actions & KRI \\
\hline $\begin{array}{l}\text { Failure to } \\
\text { develop } \\
\text { market-leading } \\
\text { products }\end{array}$ & $\begin{array}{l}\text { - Improve appropriateness } \\
\text { of human resource } \\
\text { management } \\
\text { - Systemize schedules t to } \\
\text { develop products }\end{array}$ & $\begin{array}{l}\text { - Distinguishing development of } \\
\text { leading products from improvement } \\
\text { of existing products } \\
\text { - Establishment of an exclusive } \\
\text { department for mass production of the } \\
\text { products after development of new } \\
\text { products } \\
\text { - . Security and management of product } \\
\text { road map }\end{array}$ & $\begin{array}{l}\text { Weight of development } \\
\text { of leading products } \\
\text { - No. of delayed days of } \\
\text { development schedule } \\
\text { compared to original } \\
\text { plan }\end{array}$ \\
\hline $\begin{array}{l}\text { Failure to } \\
\text { comply with } \\
\text { the date of } \\
\text { delivery for } \\
\text { products }\end{array}$ & $\begin{array}{l}\text { - Unsatisfactory } \\
\text { management of the } \\
\text { advanced index for the } \\
\text { date of delivery } \\
\text { - Lack of immediate } \\
\text { response system for the } \\
\text { delay of product delivery }\end{array}$ & $\begin{array}{l}\text { - Monitoring compliance rate of the } \\
\text { delivery date for major products } \\
\text { - Management of weekly delay change } \\
\text { rate and real-time follow-up } \\
\text { - Establishment of an exclusive } \\
\text { delivery response department for } \\
\text { client firms } \\
\text { - Internally sharing the causes of } \\
\text { delayed deliveries within the firm and } \\
\text { reinforcing their cooperative } \\
\text { responses }\end{array}$ & $\begin{array}{l}\text { - Compliance rate of } \\
\text { delivery date for } \\
\text { products } \\
\text { - Rate of weekly delivery } \\
\text { performance change } \\
\text { compared to } \\
\text { expectation }\end{array}$ \\
\hline $\begin{array}{l}\text { Failure to } \\
\text { manage supply } \\
\text { line }\end{array}$ & $\begin{array}{l}\text { - Failure to set key supply } \\
\text { line and absence of basic } \\
\text { data } \\
\text { - Expansion of strategic } \\
\text { relationship with suppliers } \\
\text { - Reinforcement of } \\
\text { innovation to cut the cost } \\
\text { for key supply line }\end{array}$ & $\begin{array}{l}\text { - Implementation of integrated database } \\
\text { for key supply line } \\
\text { - Individual approach to establish and } \\
\text { expand strategic relationships with } \\
\text { suppliers } \\
\text { - Cost innovation for key materials }\end{array}$ & $\begin{array}{l}\text { - Fidelity of information } \\
\text { management regarding } \\
\text { key supply line } \\
\text { - Implementation rate of } \\
\text { cost table } \\
\text { - Absent rate of supplied } \\
\text { materials }\end{array}$ \\
\hline
\end{tabular}

At first, TFT members doubted whether ERM systems might propose additional values to LG affiliated firms which were globalized players with over than 50 years of histories. It seemed to be true especially for the overlapping among KRIs and KPIs. Actually, large number of KRI were already managed through KPI in terms of certain risks in affiliated firms. Therefore, the TFTs first tried to find a genuine and exclusive value of KRIs to KPIs through a theoretical reasoning. TFT noticed that KPI is differentiated from KRI in its controllability. As a performance index, KPIs are required to have attributes of controllability, measurability, and importance in terms of function objectives. Among these attributes, controllability of KPI by assessee was not required for KRI. An example was a risk event of safety accidents caused by unskilled workers of LGG. LGG provides buildings maintenance services for LG affiliated firms. Most safety accidents caused by unskilled workers from workers outsourcing companies outside of LGG, which any employees of LGG could not control. LGG also could not set any KPIs internally to treat this safety accident risks, consequently causes of this risk had been out of control. However, ERM covers all the plausible risk events, causes regardless of their controllability. For example, inflation of oil price, fluctuation of foreign currencies need to be monitored even though they are not to be controlled if their impacts on firm's performances are seriously. As a consequence, ERM TFT could identify the contributable area of ERM systems and intentionally focused on uncultivated issues of existing management tools. Another differential aspect between KPI and KRI was revealed in their outcomes as project progressed. Table 4 compares KPI and KRI for a sales team of LGC. As shown in the table, the KRIs are completely distinguished from KPIs. Namely KPIs are used to achieve performance, KRIs are to warn risk factors earlier which might be obstacles to performance achievement. 
Table 4. Comparison of KPI vs. KRI (Sales Team of LGC)

\begin{tabular}{|c|c|c|c|c|c|}
\hline Perspective & KPI & Weight & Risk Event & Cause & KRI \\
\hline \multirow{3}{*}{ Finance } & Operating profit & $25 \%$ & \multirow{10}{*}{ 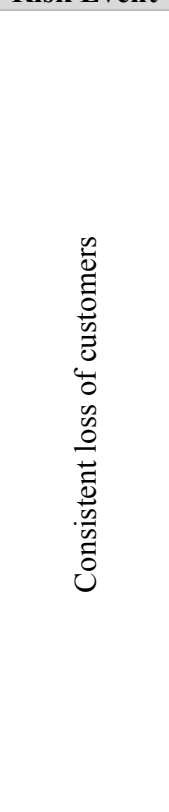 } & $\begin{array}{l}\text { Inferior price } \\
\text { competency }\end{array}$ & $\begin{array}{l}\text { Selling price } \\
\text { compared to } \\
\text { competitors* }\end{array}$ \\
\hline & Sales target & $20 \%$ & & Inferior rate of cost & $\begin{array}{l}\text { Cost of } \\
\text { competitiveness }\end{array}$ \\
\hline & $\begin{array}{l}\text { Rate of materials cost to } \\
\text { sales price } 10 \%\end{array}$ & $4 \%$ & & $\begin{array}{l}\text { Lower level of } \\
\text { customer satisfaction }\end{array}$ & $\begin{array}{l}\text { Level of customer } \\
\text { satisfaction compared } \\
\text { to competitors* }\end{array}$ \\
\hline \multirow{3}{*}{ Customer } & $\begin{array}{l}\text { ATM M/S in banking } \\
\text { industry } 65 \%\end{array}$ & $5 \%$ & & $\begin{array}{l}\text { Lack of advanced } \\
\text { negotiation }\end{array}$ & $\begin{array}{l}\text { Rate of advance } \\
\text { operation compliance }\end{array}$ \\
\hline & $\begin{array}{l}\text { No. of newly secured large } \\
\text { customers }\end{array}$ & $5 \%$ & & \multirow{2}{*}{$\begin{array}{l}\text { Change of contract } \\
\text { patterns }\end{array}$} & \multirow{2}{*}{$\begin{array}{l}\text { Sales weight by type } \\
\text { of contracts }\end{array}$} \\
\hline & Security of new customers & $5 \%$ & & & \\
\hline \multirow{3}{*}{ Process } & $\begin{array}{l}\text { Account receivables } \\
\text { turnover days }\end{array}$ & $5 \%$ & & \multirow{2}{*}{$\begin{array}{l}\text { Focus on minor no. } \\
\text { of customers }\end{array}$} & $\begin{array}{l}\text { Sales weight of top } \\
\text { three customers* }\end{array}$ \\
\hline & Inventory turnover days & $2.5 \%$ & & & $\begin{array}{l}\text { Various types of } \\
\text { customers }\end{array}$ \\
\hline & $\begin{array}{l}\text { Compliance rate of } \\
\text { delivery terms }\end{array}$ & $1 \%$ & & \multirow{2}{*}{$\begin{array}{l}\text { Failure to renew } \\
\text { contracts with } \\
\text { existing customers }\end{array}$} & Bidding failure rate \\
\hline Learning & $\begin{array}{l}\text { Evaluation of innovative } \\
\text { activities }\end{array}$ & $10 \%$ & & & $\begin{array}{l}\text { Rate of loss of large } \\
\text { customers to total } \\
\text { sales }\end{array}$ \\
\hline
\end{tabular}

In the middle of the project, ERM TFT found that risk events were not sufficiently controlled only by early warnings of KRIs. Thus, TFT developed corrective actions (CA) as required improvements to minimize the likelihood of risk events. CA development was not treated in-depth in the prior study (Liu, Zou, \& Gong, 2013), but it should be proposed to further improve systems and processes as well as to monitor indicators for successful performance of ERM. The project team proposed CA as concrete improvement measures for key risks.

\section{Stage Four: Building Sustainable ERM Systems}

It is generally accepted that final outcomes of ERM are treatment solutions themselves as KRIs, CA etc. After two years of implementations into affiliated firms, LG headquarters also assumed that all the task had done. ERM should deal with risk management as a consistent and unifying process (Beasley, Clune, \& Hermanson, 2005). Thus, IAS and LGERI staffs contrived to establish risk management (RM) systems into each affiliated firm and conglomerate as a whole. Personalized needs for RM also differed in their inherent and environmental conditions for each affiliated firm. Firms of greater decentralized controls, rather short product life cycles, and wider product line showed low levels of risk management system. Under loose RM systems, risk events of past recurred so repeatedly even if the initial risk event had been cured completely.

LGB in international trading industry had suffered those recurrences of risk events. LGB was decentralized organization structure in which each member of the firm promoted a different import of export business for different items. IAS and LGERI staffs could not find any problems with treatments process for risk event. Specialized internal auditing staffs of LGB played its role enough to provide solutions for each risk, accident in time. For serious hazardous risk events, auditing staffs issued preventive manuals and posted those risk cases on intranet bulletin board. Nevertheless, the manual for preventing risks and failure cases was not properly shared, thus well designed treatment solutions went nowhere. In LGB overall, only 11.4 cases were inquired about out of 24 important accidents disclosed in the firms' intranet; more than 500 members of the firm are still exposed to the likelihood to happen again. Further, as major trading accidents are not disclosed in the intranet, it is expected that there are quite a high number of unrevealed accidents and events. LGB case indicate that a proper RM system is essential for implemented ERM system to be operated consistently. As such, the ERM TFT developed a diagnostic procedure to identify RM systems of a firm were properly operated as in Figure 3. 
Figure 3. The four steps in the risk management framework

1. Are the risks clearly identified?

2. Are key risks set for immediate reporting to the decision maker?

3. Is there any satisfactory functions to check the potential risks before making key decisions?
7. Is there appropriate verification of the follow-up for improved issues?

- Is the risk management actually effective?

- Is the responsibility for the risk set as a performance index for management?

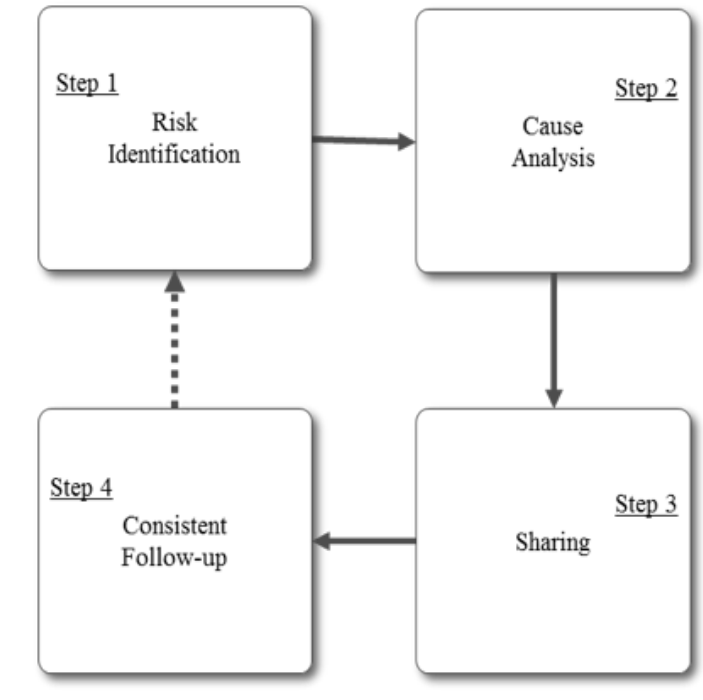

4. Does it clearly suggest required improvements through cause analysis?

- Is it only completed at the level required to report the event or accident to management?

- Is there any measurable improvement found after cause analysis?

5. Is the risk centered on a certain business department shared

with relevant departments or with the entire company?

6. Is the training and education to manage risks in advance appropriate?

- Do the members understand the contents of the manual or other methods?

Source: LG-B ERM project materials

\section{Stage Five: How to Motivate Affiliate Firms Over Some Obstacles}

Even though ERM implementations had been completed, there existed other obstacles for ERM systems to be operated voluntarily and consistently. Sooner or later, IAS and LGERI staffs found that consistent operations of ERM systems were not in use. First obstacle was managers' indifference to ERM. In general, agency costs are reduced as CEOs' tenure or stock shares are increased (Barker \& Mueller, 2002; Demsetz, 1983). Managers of LG affiliated firms who are to renew their contracts every three years have to prove their contributions through KPIs as increased sales and net income. Other reason was on the discrepancies of interests among conglomerate headquarters and affiliated firms. The initiative motivations of ERM implementations came from headquarters not from affiliated firms. Some affiliated firms even refused to adopt a top-down approach implementations. Therefore, consistency of ERM activities requires creation of an exclusive ERM organization and checks and balances to motivate its embeddedness as basic conditions. Generally, an exclusive organization needs to secure consistent activation of the corresponding affairs. Thus, IAS and LGERI staffs designed an exclusive ERM organization connected with the existing internal control team inside each affiliated firm.

Even after organizing ERM specialized function, there emerged second barriers. It was about how to motivate employees belong to ERM functions in each affiliated firm. Most employees avoided to take part in ERM affairs. That was because serious risk events do not happen so often that managers tend to pay less attention to ERM as time goes. It was also heavy burden to take responsibility when uncontrollable events or accidents occur. Further, as there were not many tasks shown except monitoring the indicators, ERM work seemed to be recognized as a post of leisure. As a result, early on, the independent ERM department was integrated into the internal auditing team in order for the organization to promote risk management and auditing together.

For the first and second obstacles above, IAS and LGERI staffs designed an external monitoring and auditing organization based on the IAS team of the conglomerate headquarters level in order to motivate each firm to implement ERM. Table 5 shows ERM functions and organizations in LGA. It consisted of a risk management committee, which was newly established with the embeddedness of ERM; a CRO; a risk management bureau; an internal control team, including an audit committee as the existing internal control organization; and the IAS team. 
Table 5. Composition of ERM implementation organizations (LGA)

\begin{tabular}{|c|c|c|c|}
\hline \multirow[b]{2}{*}{ Organization } & \multirow[b]{2}{*}{ Key functions } & \multicolumn{2}{|c|}{ Person in charge and activities } \\
\hline & & Entire firm & $\begin{array}{c}\text { Business } \\
\text { headquarters }\end{array}$ \\
\hline $\begin{array}{l}\text { Risk } \\
\text { Management Committee } \\
\text { (RMC/RMSC) }\end{array}$ & $\begin{array}{l}\text { - Establish risk management standards and } \\
\text { policies } \\
\text { - Integrate and adjust key issues related to risks } \\
\text { - Check and discuss business risks and the } \\
\text { solutions } \\
\text { - Determine key risks for entire firm/business } \\
\text { dept. }\end{array}$ & $\begin{array}{l}\text { RMC: Quarterly } \\
\text { meeting with } \\
\text { members of the } \\
\text { management } \\
\text { committee }\end{array}$ & $\begin{array}{l}\text { RMSC: Quarterly } \\
\text { meeting within } \\
\text { members of the } \\
\text { management } \\
\text { committees by } \\
\text { business headquarters }\end{array}$ \\
\hline CRO & $\begin{array}{l}\text { - Extend ERM to entire firm } \\
\text { - Final responsibility for general management } \\
\text { of risks }\end{array}$ & Adjunct to $\mathrm{CFO}$ & \\
\hline RM Bureau & $\begin{array}{l}\text { - Identify and assess risks regarding entire firm } \\
\text { and business dept. } \\
\text { - Risk management and action plan monitoring } \\
\text { - Support practical risk management affairs in } \\
\text { the field } \\
\text { - Development of education and change } \\
\text { management programs }\end{array}$ & $\begin{array}{l}\text { Newly established } \\
\text { RM team under } \\
\text { management } \\
\text { planning department }\end{array}$ & $\begin{array}{l}\text { Utilization of the IAS } \\
\text { team under } \\
\text { management support } \\
\text { department }\end{array}$ \\
\hline Risk Owner & $\begin{array}{l}\text { - Regularly identification and assessment of the } \\
\text { risks } \\
\text { - General risk management activities } \\
\text { - Execute corrective actions by risk }\end{array}$ & \multicolumn{2}{|c|}{$\begin{array}{l}\text { Departmental heads/ sales managers/ plant } \\
\text { manager, etc. }\end{array}$} \\
\hline $\begin{array}{l}\text { Audit Committee } \\
\text { (Internal Control Team) }\end{array}$ & $\begin{array}{l}\text { - Diagnosis and report on current risk } \\
\text { management processes } \\
\text { - Regular and irregular assessment of the } \\
\text { adaptability and operation systems to key risks }\end{array}$ & \multicolumn{2}{|c|}{ Internal control department of each firm } \\
\hline HQ RM Team & $\begin{array}{l}\text { - Diagnosis and report on current risk } \\
\text { management processes } \\
\text { - Regular and irregular assessment of the } \\
\text { adaptability and operation systems to key risks }\end{array}$ & \multicolumn{2}{|c|}{ Conglomerate headquarters } \\
\hline
\end{tabular}

The third obstacle was for managers to stay within the original risk profiles the same as ERM was first implemented. After the ERM implementations, each firm featured different risks. Most affiliated firms maintained the original risk profile as it was first implemented. As a firm's operational and strategic risks change continuously, it is essential to follow them up consistently. Considering three obstacles, conglomerate headquarters contrived to design a systematic reporting systems under which affiliated firms should apply to regular operations of ERM activities. Table 6 shows the template each affiliated firm used to report the status of ERM activities during the previous year to the IAS team at the beginning of the following year. As in Table 6, each affiliated firm should report risk issues to headquarters such as identifying updated risk profile, any accidents or hazards, RM plans for next year. IAS and headquarters also were to play its roles in introducing advanced ERM methodologies, benchmarking cases, and providing consulting advices with LGERI staffs. 
Table 6. Annual reports for affiliated firms and headquarters audit team

\begin{tabular}{|c|c|c|}
\hline Summary & $\begin{array}{l}\text { - Audit teams from each affiliated firm and the gro } \\
\text { following year in documents for themselves } \\
\text { - Leads to consistent ERM and effectively support }\end{array}$ & $\begin{array}{l}\text { report the current status of ERM and the plan for the } \\
\text { ternal control at group level }\end{array}$ \\
\hline $\begin{array}{c}\text { Annual } \\
\text { processes }\end{array}$ & $\begin{array}{l}\text { - End of December at year } \mathrm{t} \text { : Each affiliated firm } \mathrm{r} \\
\text { the following year } \\
\text { - Proposals for improvement suggestions through } \\
\text { by affiliated firms for year }(\mathrm{t}-1) \text {, held between Jar } \\
\text { team } \\
\text { - End of March at year }(\mathrm{t}+1) \text { : Select and give awar }\end{array}$ & $\begin{array}{l}\text { ort the main issues of the past on year \& the plan for } \\
\text { tual field inspection and diagnosis of ERM activities } \\
\text { ary and March of year }(t+1) \text { by the headquarters audit } \\
\text { o the best ERM practice at year } t\end{array}$ \\
\hline \multirow{11}{*}{ Report } & Report by each affiliated firm & Diagnosis by $\mathrm{HQ}$ audit team \\
\hline & 1. Report of RM process & 3. RM-based auditing \\
\hline & $\begin{array}{l}\text { 1-1. Key risks to manage: Distinction of business } \\
\text { and operational risks }\end{array}$ & 3-1. Diagnosis result of the RM process \\
\hline & 1-2. KRI for top ten-rank risks & $\begin{array}{l}\text { 3-2. Evaluation of appropriate governance for } \\
\text { internal control of risks }\end{array}$ \\
\hline & $\begin{array}{l}\text { 1-3. Trend of annual KRI performance for top ten- } \\
\text { rank risks }\end{array}$ & $\begin{array}{l}\text { 3-3. Diagnosis of the possible repetition of past } \\
\text { events or incidents }\end{array}$ \\
\hline & $\begin{array}{l}\text { 1-4. Response to the KRI in warning zone (yellow, } \\
\text { red) }\end{array}$ & $\begin{array}{l}\text { 3-4. Diagnosis or check of the follow-ups suggested } \\
\text { in the previous year, etc. }\end{array}$ \\
\hline & $\begin{array}{l}\text { 1-5. Details of the events and incidents and the } \\
\text { handling }\end{array}$ & \\
\hline & 2. RM plan for the following year & 4. Others \\
\hline & 2-1. Strategic target for the following year & $\begin{array}{l}\text { 4-1. Selection and rewarding best practices of the } \\
\text { year among affiliated companies and spread } \\
\text { them to all other affiliated firms }\end{array}$ \\
\hline & $\begin{array}{l}\text { 2-2. Key risks to manage: Addition of detailed } \\
\text { information about risk factors added or } \\
\text { changed compared to the previous period }\end{array}$ & $\begin{array}{l}\text { 4-2. Perform regular consultation activities based on } \\
\text { LG In-house Consulting }\end{array}$ \\
\hline & $\begin{array}{l}\text { 2-3. Profit and loss simulation for strategic risks, } \\
\text { including economic risk, etc. }\end{array}$ & \\
\hline $\begin{array}{l}\text { Irregular } \\
\text { activities }\end{array}$ & \multicolumn{2}{|c|}{$\begin{array}{l}\text { By holding an ERM seminar in every } 2-3 \text { years, LG group-affiliated firms can share their best practices. LG } \\
\text { In-house Consulting introduce successful cases from advanced global corporations. }\end{array}$} \\
\hline
\end{tabular}

The fourth obstacle was how to secure timely senses and responds for risk events. LG headquarters needed to monitor KRIs and to respond spontaneously not to minimize the losses incurred. Reflecting LG Card distress, if the earlier signals of rapid increases of default risks were reported to conglomerate headquarters immediately, there would not be the disastrous results. For this, LG Group benchmarked Samsung Group, which also had the same experience of bankruptcy of its affiliated firm in credit card services. In case of Samsung, its restructuring headquarters designated core KRI, which indicated that real-time monitoring was important for its affiliated firms in the financial industry, such as Samsung Life Insurance, Samsung Fire and Marine Insurance, and Samsung Card. It also set a system of interwork between the conglomerate headquarters and the affiliated firms to observe the indicators in real time. In addition, it employed two or three financial experts to interpret the meaning of the indicators within the IAS team to complete the system.

To summarize, the case of LG group evoke that three conditions are required to maintain ERM process consistent and effective since it settled down. First, an independent position is required to minimize the moral hazard of the management of each affiliated firm. Second, expert competencies are required to analyze the risky situation of the affiliated firms by accurately reading the KRI and to propose suitable responses to them. Third, there should be a controlling authority to ensure active participation by the management groups of the affiliated firms, which could become passive on ERM. There were some findings that we did not realize before actual implementations, it was still more because LG was not the case of an independent firm but among conglomerate headquarters and its affiliated firms. It is not so difficult to find conglomerate business group over Asian, Europe, and the other regions. Thus we expects the findings of this study surely to be a guidance for those organizations, especially in consideration of the ambiguity of COSO ERM guidelines. 


\section{CONCLUSION}

Since the release of COSO 2004 ERM framework, dozens of organizations have adopted ERM systems. There still exist limitations on how to put COSO framework into actions as a value added internal control systems both in terms of theoretical and practical aspects. This paper attempts to mitigate those limitations with the case of LG group which implemented ERM systems into twelve diversified affiliated firms.

The contributions of this paper are summarized as follow. First, this paper suggests that ERM systems be an effective management device to minimize agency costs which the internal control systems of managerial accounting do not fully resolve. Prior studies have focused on the function of ERM as early warning systems to prevent fatal losses. And there were few studies which highlight the internal control functions of in order to minimize agency costs. Second, confirming the limitations of ambiguity of COSO 2004 ERM guidance (Arena, Arnaboldi, \& Azzone, 2010; O'Donnell, 2005), this study provides implementations of ERM into diversified conglomerate group. Case of LG group and its affiliated firms also identified that the applications of ERM framework vary depending on their industries and other business routines.

Through the case, we suggest that ERM could be an effective tool to resolve agency costs among the affiliated firms and headquarters of the group within most Asian conglomerates. ERM, as a new management tool, expands the existing research area of agency costs between owners and managers in an independent firm in much of the prior research on the conglomerate. Family-owned conglomerate group are common governance structure in East Asia and Western Europe. We also propose rather unprecedent applications in each stage as top-down based approach to identify risk events, emphasizing corrective actions as treatments, causal map to grasp the whole relations among losses, risk events, causes at a glance. Some intermediate outcomes are intrinsic to conglomerate group such as the methods on how to balance gaps of ERM needs between conglomerate headquarters and affiliated firms, considering the needs for headquarters to minimize agency costs in evaluating risk events. We expect that those findings to provide practical insights for conglomerate groups to implement ERM to obtain meaningful performances. However, findings of this study are conditional to be generalized due to the centralized control right provided by majority shareholders, as in the case of Korean the conglomerate groups. For example, top-down ERM embeddedness in affiliated firms could be rejected, and the function of ERM in the conglomerate headquarters could be reduced. This might be difficult to in the conglomerate groups in the United States or Europe. Thus, the result can mainly be extended to family-type the conglomerate groups in East Asia, including Japan and China. However, apart from the strength of the central controllability, common consideration factors for ERM operation at the conglomerate group level as found in this study are expected to be applied to others in general.

\section{AUTHOR BIOGRAPHIES}

Sangil Kim is an assistant professor in the School of Business at Ajou University. Research interests are internal control, corporate governance, Korean chaebol, and other financial accounting issues. E-mail: sikim@ajou.ac.kr

Jungmin Yoo is an assistant professor in the College of Business Management at Hongik University. Research interests include corporate governance, insider trading, executive compensation and other accounting issues. E-mail: jmyoo@hongik.ac.kr

\section{REFERENCES}

Arena, M., Arnaboldi, M., \& Azzone, G. (2010). The organizational dynamics of enterprise risk management. Accounting, Organizations and Society, 35(7), 659-675.

Arena, M., Arnaboldi, M., \& Azzone, G. (2011). Is enterprise risk management real? Journal of Risk Research, 14(7), 779-797.

Barker, V. \& Mueller, G. CEO characteristics and firm R\&D spending, Management Science, 48(6), 782-801.

Ball, R., Kothari, S. P., \& Robin, A. (2000). The effect of international institutional factors on properties of accounting earnings. Journal of accounting and economics, 29(1), 1-51.

Beasley, M., Branson, B., \& Hancock, B. (2010). COSO's 2010 report on enterprise risk management: Current state of enterprise risk oversight and market perceptions of COSO's ERM framework. New York, NY: Committee of Sponsoring Organizations of the Treadway Commission.

Beasley, M., Clune, R., \& Hermanson, D. (2005). Enterprise risk management: An empirical analysis of factors associated with 
the extent of implementation. Journal of Accounting and Public Policy, 24, 521-531.

Brickley, J., Smith, C., \& Zimmerman, J. (1997). Managerial economics and organizational architecture, Burr Ridge, IL: Richard D. Irwin.

Bushman, R. M., \& Smith, A. J. (2001). Financial accounting information and corporate governance. Journal of accounting and Economics, 32(1), 237-333.

Carr, V.\& Tah, J. H. V. (2001). A fuzzy approach to construction risk assessment and analysis: Construction project risk management system. Advances in Engineering Software, 32(10), 847-857.

COSO (2004). Enterprise risk management. Committee of the Sponsoring Organizations of the Treadway Commission.

Demsetz, H. (1983). The structure of ownership and the theory of the firm, Journal of Law and Economics, 26, 375-390.

Demsetz, H. \& Lehn, K. (1985). The structure of corporate ownership: causes and consequences, Journal of Political Economy, 93(6), 1155-1177.

Franceschini, F. \& Galetto, M. (2001). A new approach for evaluation of risk priorities of failure modes in FMEA. International Journal of Production Research, 39(10), 2991-3002.

Fraser, I. \& Henry, W. (2007). Embedding risk management: structures and approaches. Managerial Auditing Journal, 22(4), 392-409.

Gordon, L., Loeb, M., \& Tseng, C. (2009). Enterprise risk management and firm performance: A contingency perspective. Journal of Accounting and Public Policy, 28, 301-327

Hoyt, R., \& Liebenberg, A. (2011). The value of enterprise risk management: Evidence from the U.S. insurance industry. Journal of Risk and Insurance, 78(4), 795-822

Ittner, C., Larker, D., \& Randall, T. (2003). Performance Implications of strategic performance measurement in financial services firms. Accounting, Organizations and Society, 28(7), 715-741.

Jensen, M., \& Meckling, W. (1976). Theory of the firm: managerial behavior, agency costs and ownership structure. Journal of Financial Economics, 3, 305-360.

Knechel, R. (2002). The role of the independent accountant in effective risk management. Review of Business and Economics, $47(1), 65-86$

Liebenberg, A., \& Hoyt, R. (2003). The determinants of enterprise risk management: Evidence from the appointment of chief risk officers. Risk Management and Insurance Review, 6, 37-52.

Liu, J. , Zou, P., \& Gong, W. (2013). Managing project risk at the enterprise level: exploratory case studies in China. Journal of Construction Engineering \& Management, 139(9), 1268-1274.

McNamee, D., \& Selim, G. (1998). Risk management: changing the internal auditor's paradigm. Institute of Internal Auditors Research Foundation. 1-218.

Meulbroek, L. K. (2002). A senior manager's guide to integrated risk management. Journal of Applied Corporate Finance, 14(4), 56-70.

O'Donnell, D. (2005). Enterprise risk management: A systems-thinking framework for the event identification phase. International Journal of Accounting Information Systems, 6(3), 177-195.

Pagach, D., \& Warr, R. (2011). The characteristics of firms that hire chief risk officers. Journal of Risk and Insurance, 78, 185211.

Page, M. \& Spira, L. (2004). The turnbull report, internal control and risk management: The developing role of internal audit. Institute of Chartered Accountants: Scotland.

Porter, M. E. (2008). The five competitive forces that shape strategy. Harvard business review, 86(1), 25-40.

Verrecchia, R. E. (1983). Discretionary disclosure. Journal of Accounting and Economics 5: 179-194. 
NOTES 